\title{
First report of peanut black rot caused by Cylindrocladium parasiticum in Guizhou province, China
}

\author{
Xia Zhang ${ }^{1} \cdot$ Manlin $\mathrm{Xu}^{1} \cdot$ Jing $\mathrm{Yu}^{1} \cdot$ Zhiqing Guo $^{1} \cdot$ Juxiang $\mathrm{Wu}^{1} \cdot$ Yucheng $\mathrm{Chi}^{1}{ }^{10}$
}

Received: 29 March 2021 / Accepted: 3 June 2021 / Published online: 9 June 2021

(c) Società Italiana di Patologia Vegetale (S.I.Pa.V.) 2021

Keywords Cylindrocladium black rot $\cdot$ Cylindrocladium parasiticum $\cdot$ Pathogenicity

In 2017, a peanut disease resembling Cylindrocladium black rot (CBR) was found in Guiyang city, Guizhou province, China. The basal stems, pods and taproots became black and rotten, and reddish orange spherical fruiting bodies appeared in those lesions at the later stage. Disease incidence was approximately $5 \%$ in the area we investigated. The pathogen was isolated from basal stem lesions on potato dextrose agar (PDA), and incubated at $25^{\circ} \mathrm{C}$ under dark conditions. Fungal colonies were initially white, becoming pale buff, and a reddish brown pigment was produced with age. The apical branches of the conidiophores were bottle shaped, and the terminal vesicles were spherical or nearly spherical. Conidia were hyaline, cylindrical, narrow at one end, with 1 to 3 septa, and measured 44.5 to $72.6 \times 4.1$ to $7.2 \mu \mathrm{m}$.

Molecular identification was performed by sequencing three genes of a representative isolate ZHX6. Beta tubulin (Glass and Donaldson 1995), elongation factor $1-\alpha$ and histone 3 (Crous et al. 2004) (GenBank accession Nos. MW654483, MW654484, MW654485) of ZHX6 shared 100, 100, and $99.55 \%$ sequence identity with Cylindrocladium parasiticum (telomorph. Calonectria ilicicola Boedijn and Reitsma 1950) (MK189210, MK000557, MH937733). The isolate was identified as $C$. parasiticum based on phylogenetic analysis which was done using Neighbor-Joining (NJ) analysis based on those gene sequences. Those results showed that the molecular identification was consistent with the morphological features.

For pathogenicity assay, two-week-old peanut (Luhua No.8) seedlings were inoculated with two mycelial plugs

Xia Zhang and Manlin Xu contribute equally to the paper

Yucheng Chi

87626681@163.com

1 Shandong Peanut Research Institute, Qingdao, Shandong,

China
(8 $\mathrm{mm}$ in diameter) in a growth chamber $\left(30^{\circ} \mathrm{C}\right.$ in the day and $25{ }^{\circ} \mathrm{C}$ at night, a 12 -h photoperiod and $80 \% \mathrm{RH}$ ). All inoculated seedlings exhibited typical basal stem and root rot symptoms two weeks after inoculation. No symptoms were observed on control plants treated with sterile distilled mycelial plugs, and C. parasiticum was consistently re-isolated from symptomatic tissue. To our knowledge, this is the first report of $C$. parasiticum causing peanut black rot in Guizhou, China.

\section{Declarations}

Ethical statement The authors declare that they have no known competing financial interests or personal relationships that could have appeared to influence the work reported in this paper. Some or all data, models, or code generated or used during the study are available from the corresponding author by request or magazine publisher. The materials we study are harmless to people and animals.

\section{References}

Boedijn KB, Reitsma J (1950) Notes on the genus Cylindrocladium (Fungi: Mucedinaceae). Reinwardtia 1(1): 51-60

Crous PW, Groenewald JZ, Risede J et al (2004) Calonectria species and their Cylindrocladium anamorphs: species with sphaeropedunculate vesicles. Stud Mycol 50(2004):415-430. https://doi.org/ 10.3114/sim.55.1.213

Glass NL, Donaldson GC (1995) Development of primer sets designed for use with the PCR to amplify conserved genes from filamentous ascomycetes. Appl Environmental Microbiol 61(4):1323-1330

Publisher's note Springer Nature remains neutral with regard to jurisdictional claims in published maps and institutional affiliations. 